\title{
Asymmetric introgression between Pinus sibirica and Pinus pumila in the Aldan plateau (Eastern Siberia)
}

\author{
Elena A. Petrova', Evgeniya A. Zhuk', Aleksandr G. Popov' ${ }^{1}$, Aleksandr A. Bondar², Mariana M. \\ Belokon $^{3}$, Sergei N. Goroshkevich', Galina V. Vasilyeva ${ }^{1 *}$
}

\begin{abstract}
${ }^{1}$ Institute of Monitoring of Climatic and Ecological Systems, Siberian Branch of the Russian Academy of Sciences, 10/3, Akademicheskiy ave., Tomsk, 634055, Russia.

${ }^{2}$ Institute of Chemical Biology and Fundamental Medicine, Siberian Branch of the Russian Academy of Sciences, 8 , Lavrentiev Ave., Novosibirsk, 630090, Russia.

${ }^{3}$ Vavilov Institute of General Genetics, Russian Academy of Sciences, 3, Gubkina str., Moscow, 119333, Russia.
\end{abstract}

* Corresponding author: Galina V. Vasilyeva, E-mail: galina_biology@mail.ru

\begin{abstract}
Pinus sibirica and P. pumila are Asian five-needle pines with vast geographic distributions that are partially overlapping. Natural hybrids with intermediate morphology have been found previously, but there is a lack of evidence of ongoing introgression. The goal of our study was to elucidate the genetic structure of $P$. sibirica and P. pumila populations growing in the north-east of their sympatry zone (Aldan plateau) using cytoplasmic DNA markers. All studied P. sibirica and P. pumila trees had usual species-specific growth habits. Using nad1 intron2 of mitochondrial DNA (mtDNA) and trnV of chloroplast DNA (cpDNA) we found that trees morphologically identified as $P$. sibirica had pumila-specific mtDNA. Moreover, some of them also had pumila-specific cpDNA. P. pumila trees were typical and had pumila-type cytoplasmic DNA markers. These results suggest that interspecific hybridization took place long ago and lead to introgression and cryptic hybrids with $P$. sibirica appearance and P. pumila mtDNA.
\end{abstract}

Keywords: : gene flow, hybridization, introgression, gymnosperms, chloroplast DNA, mitochondrial DNA

\section{Introduction}

At the present time, there are no doubts about the great importance of hybridization in plant evolution. Interspecific hybridization is widespread among trees and facilitated by anemophily and lack of strong selection pressure in high fecundity (Stebbins, 1959; Grant, 1981; Koropachinskiy and Milyutin, 2006). In tree species, including conifers, the main isolation mechanisms are geographic, ecological and phenological isolation which connected with incomplete reproductive isolation and, therefore, they are ineffective in preventing interspecific gene exchange.

Natural hybridization can lead to introgression. The term "introgression" was proposed by Anderson as back-crosses of hybrids with one or both parental species that resulted in gene transfer from one species to another (Anderson, 1953). Independently of Anderson, the phenomenon was also described by the Russian botanist E.G. Bobrov who called it "hybrid blending of the species" or in Russian "гибридное смешение видов" (Bobrov, 1944; 1961). First of all, introgression is caused by incomplete reproductive isolation that enables gene flow between parental species and F1 hybrids. Cross-pollination can result in two categories of reciprocal hybrids (Chen et al., 2004; Thórsson et al., 2001), or back-crosses can occur with one parental species and lead to unidirectional introgression (Petit et al., 2004; Burgess et al., 2005; Godbout et al., 2012).

Hybridization of Siberian stone pine (Pinus sibirica Du Tour) and Siberian dwarf pine (P. pumila (Pall.) Regel) is one of the many 
examples of interspecific hybridization in pines. However, the peculiarity of this pair of the species is the contrasting life forms; $P$. sibirica is an upright tree and P. pumila is a prostrate tree. Hybrids of the two species have been found in many parts of the huge area where the species grow together (Goroshkevich, 2004; Goroshkevich et al., 2008). The first genetic evidence of natural hybridization between $P$. sibirica and $P$. pumila was obtained by allozyme analysis (Politov et al., 1999). The hybrids have intermediate morphology and presumably they are F1 (Goroshkevich, 1999; Goroshkevich et al., 2008). They are fertile and have a significantly reduced but sufficient seed efficiency (Goroshkevich et al., 2008; Vasilyeva, 2014) and crossability with parental species (Vasilyeva and Goroshkevich, 2013). Previously we have identified back-crosses in hybrid populations in the northern Baikal region only at the embryo stage. We studied embryos from seeds and found that embryos from the hybrid trees partly resulted from pollination by $P$. sibirica and $P$. pumila pollen i.e. they were back-crosses (Petrova et al., 2007; 2008). Therefore, the search for hybrids morphologically similar to one of the parental species remains an important task in order to prove the ongoing introgression.

The chloroplast and the mitochondrial DNA in pines is paternally and maternally inherited, respectively, (Neale and Sederoff, 1989; Mogensen, 1996; Petit and Vendramin, 2007) and makes it possible to determine the direction of the gene flow. The goal of our study was to elucidate the genetic structure of $P$. sibirica and $P$. pumila populations growing in the north-eastern area of their sympatry zone (Aldan plateau) using cytoplasmic DNA markers and to clarify the introgression issue.

\section{Materials and Methods}

\section{Sample collection}

The Aldan plateau is characterized by an extreme continental climate. The temperature in the warmest month is $13-18{ }^{\circ} \mathrm{C}$. The sum of the temperatures above $10^{\circ} \mathrm{C}$ is $700-1400{ }^{\circ} \mathrm{C}$. The frost-free season usually lasts $60-90$ days. The climate is temperately humid with annual precipitation of $350-500 \mathrm{~mm}$. The main forest tree is larch, which occupies about $76 \%$ of the forest covered area. Approximately $12 \%$ of the area is occupied by Siberian dwarf pine (Pozdnyakov, 1969). Siberian stone pine rarely forms pure stands in the area and is mainly found as admixture in the larch forest.

Adult trees of $P$. sibirica and $P$. pumila from two locations in the north-eastern part of their sympatry zone were the objects of the study (Fig. 1). The first location (Aldan, 58 $20^{\prime} 35^{\prime \prime} \mathrm{N}$, $125^{\circ} 16^{\prime} 57^{\prime \prime} \mathrm{E}, 750 \mathrm{~m}$ a.s.l.) is situated $5 \mathrm{~km}$ from Aldan town, near Leninskiy settlement. $P$. sibirica was found here in the mixed forest where the main species were Larix sp., Pinus sylvestris, and Betula sp. and Picea sp. as admixtures. P. pumila occurred in the understory. Betula divaricata, Duschekia fruticosa, Prunus padus, Sorbus sp., Juniperus sp., Salix sp. and Rosa sp. also occurred in the understory. The second location (Tommot, $58^{\circ} 26^{\prime} 39^{\prime \prime} \mathrm{N}, 126^{\circ} 14^{\prime} 12^{\prime \prime} \mathrm{E}, 627 \mathrm{~m}$ a.s.l.) is $15 \mathrm{~km}$ from Tommot town, near the neglected Bezymyaniy settlement. Pinus sibirica was also found there in the mixed forest, but in this stand there was no P. sylvestris. Pinus pumila, Duschekia fruticosa, Prunus padus, Sorbus sp., Juniperus sp. and Betula sp. were in the understory.

Needles were collected from randomly chosen 59 P. sibirica individuals ( 15 trees in Aldan and 44 trees in Tommot) and 32 P. pumila individuals ( 15 trees in Aldan and 17 trees in Tommot). In both locations, average tree height of $P$. sibirica was about $16 \mathrm{~m}$, trunk diameter was about $20 \mathrm{~cm}$, and trees were about 120-150 years old. P. pumila had a common cup-like growth form and reached a height of about $4 \mathrm{~m}$. We found no typical hybrids with intermediate habit in the populations studied. All trees had typical species-specific morphology.

\section{Cytoplasmic DNA analysis}

Nad1 intron2 locus was used as a mitochondrial (mtDNA) marker, as proposed previously by Gugerli et al. (2001). The fragment overlapping rbcL-trnV region ( 3600 bp) was chosen as a suitable chloroplast DNA (cpDNA) marker because studied species differ in the restriction site for Tru9l; it is present in $P$. pumila and absent in $P$. sibirica (personal communication with Dr. Vladimir L. Semerikov). Analysis of trnV sequences of the studied species from GeneBank (AB455836.1, AB019870.1) showed that $P$. sibirica and $P$. pumila are indeed distinguished by the nucleotide substitution. To verify the cpDNA marker, several $P$. sibirica and $P$. pumila individuals from various geographical regions out of the sympatry zone were used (Table 1, Fig. 1). All the trees were grown in the clone archive and geographical cultures at the Kedr field station, managed by the Institute of Monitoring of Climatic and Ecological Systems SB RAS ( $56^{\circ} 13^{\prime} \mathrm{N}, 84^{\circ} 51^{\prime} \mathrm{E}, 78 \mathrm{~m}$ a.s.l., Tomskaya oblast, Russia).

Table 1

Sample list of reference P. sibirica and P. pumila trees used to test the cpDNA marker

\begin{tabular}{lll}
\hline Species & Origin & Geographic coordinates \\
\hline P. sibirica & Republic of Khakassia & $52^{\circ} 30^{\prime} \mathrm{N}, 90^{\circ} 05^{\prime} \mathrm{E}, 350 \mathrm{~m}$ a.s.l. \\
& Sverdlovskaya Oblast & $57^{\circ} 15^{\prime} \mathrm{N}, 60^{\circ} 1^{\prime} \mathrm{E}, 300 \mathrm{~m}$ a.s.l. \\
& Yamalo-Nenets Autonomous Okrug & $65^{\circ} 50^{\prime} \mathrm{N}, 78^{\circ} 10^{\prime} \mathrm{E}, 30 \mathrm{~m}$ a.s.l. \\
& Tomskaya Oblast & $56^{\circ} 31^{\prime} \mathrm{N}, 84^{\circ} 39^{\prime} \mathrm{E}, 99 \mathrm{~m}$ a.s.l. \\
& $44^{\circ} 05^{\prime} \mathrm{N}, 145^{\circ} 49^{\prime} \mathrm{E}, 150 \mathrm{~m}$ a.s.l. \\
& Kunashir Island & $59^{\circ} 34^{\prime} \mathrm{N}, 150^{\circ} 48^{\prime} \mathrm{E}, 116 \mathrm{~m}$ a.s.l. \\
& Magadanskaya Oblast & $43^{\circ} 41^{\prime} \mathrm{N}, 134^{\circ} 11^{\prime} \mathrm{E}, 1854 \mathrm{~m}$ a.s.l. \\
& Primorsky Kray & $46^{\circ} 51^{\prime} \mathrm{N}, 143^{\circ} 09^{\prime} \mathrm{E}, 50 \mathrm{~m}$ a.s.l.
\end{tabular}




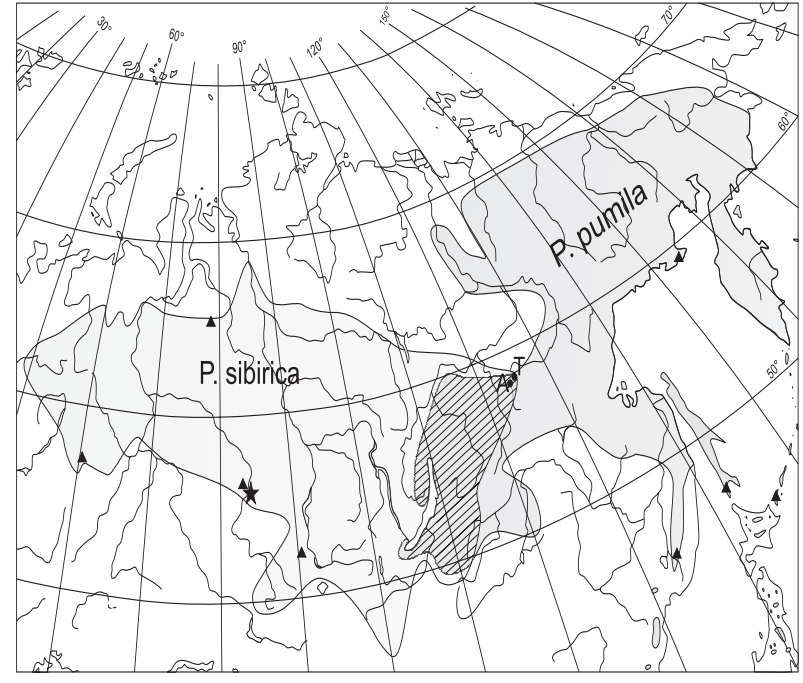

Figure 1

Geographic distribution of the species and their sympatry zone (shaded region). Studied populations: A - Aldan, T-Tommot. Asterisk - Kedr field station (Tomskaya oblast); triangle - the origin of $P$. sibirica and P. pumila trees used for TrnV verification.

Total DNA was extracted from the needles using the CTAB method (Doyle and Doyle, 1987). The DNA fragment of the nad1 intron2 was amplified by PCR using primers previously described in the study of $B$. Demesure et al. (1995), namely forward: 5'-GCA TTA CGA TCT GCA GCT CA-3' and reverse: 5'-GGA GCT CGA TTA GTT TCT GC-3! Nad1 intron2 locus was amplified with a typical mix of $40 \mu \mathrm{lPCR}$ containing $1 \times$ Taq buffer, $0.2 \mathrm{mM}$ dNTPs, $2.5 \mathrm{mM} \mathrm{MgCl}, 0.2 \mu \mathrm{M}$ of forward and reverse primers (Gugerli et al., 2001), approximately $100 \mathrm{ng}$ of plant genomic DNA and $30 \mathrm{u} / \mathrm{ml}$ of Taq DNA Polymerase (Biosan, Russia). Cycling conditions for PCR consisted of an initial $1 \mathrm{~min} 30 \mathrm{~s}$ hot start at $95^{\circ} \mathrm{C}$, followed by 40 cycles of denaturation at $95^{\circ} \mathrm{C}$ for $10 \mathrm{~s}$, annealing at $62^{\circ} \mathrm{C}$ for $15 \mathrm{~s}$ and extension at $72{ }^{\circ} \mathrm{C}$ during 2 min $30 \mathrm{~s}$, with a final incubation at $72{ }^{\circ} \mathrm{C}$ for $10 \mathrm{~min}$ and then remaining at $4{ }^{\circ} \mathrm{C}$. Amplified products were analyzed by capillary electrophoresis using a Shimadzu MultiNA MCE-202 instrument (Shimadzu, Japan) with a DNA-12000 reagent kit, or by electrophoresis in $1.5 \%$ agarose gel with $1 \times$ Tris-acetate-EDTA buffer.

Fragment rbcL-trnV was obtained by PCR amplification. The PCR mixture (40 $\mu \mathrm{l}$ volume) contained $1 \times$ Taq buffer, 0.2 $\mathrm{mM}$ dNTPs, $1.7 \mathrm{mM} \mathrm{MgCl} \mathrm{2}_{2}, 0.2 \mu \mathrm{M}$ of selected forward (5'-TCG ATT CGT CCG ATC CACG-3 ${ }^{\prime}$ ) and reverse (5'-TCG CAT TGG GCT CTT TCAT- $3^{\prime}$ ) primers, approximately $100 \mathrm{ng}$ of plant genomic DNA and $30 \mathrm{u} / \mathrm{ml}$ of Taq DNA Polymerase (Biosan, Russia). The cycling profile was as follows: hot start at $95^{\circ} \mathrm{C}$ for $1 \mathrm{~min} 30 \mathrm{~s}$, followed by 40 cycles of denaturation at $95^{\circ} \mathrm{C}$ for $10 \mathrm{~s}$, annealing at $59^{\circ} \mathrm{C}$ for $15 \mathrm{~s}$ and extension at $72^{\circ} \mathrm{C}$ during $1 \mathrm{~min}$ and final hold at $4{ }^{\circ} \mathrm{C}$. Post-PCR cleanup was conducted by absorption on AMPure XP magnetic particles (Agencourt, USA), and then fragments were sequenced using a BigDye Terminator v3.1 Cycle Sequencing Kit (Thermo, USA) and analyzed in an
ABI 3130xl genetic analyzer (Applied Biosystems, USA). Sequencing of the fragments was carried out in the SB RAS Genomics Core Facility (ICBFM SB RAS, Novosibirsk, Russia). Indeed, a polymorphic position in the rbcL-trnV which discriminates studied species was located at $\operatorname{trn} V$ side (Table 2). A short fragment in TrnV intron determined interspecific differentiation: TGAA in P. sibirica and TTAA in P. pumila. Therefore, amplicons were sequenced using reverse primer and sequenced fragments had a discriminating position.

Table 2

Species-specific differences in cytoplasmic DNA in P. sibirica and P.pumila

\begin{tabular}{cccc}
\hline Locus & Species & Species-specific difference & Reference \\
\hline nadl intron2 & P. sibirica & Length (2530 bp) & Gugerli et al., 2001 \\
mtDNA & P. pumila & Length (2181 bp) & \\
trnV cpDNA & P. sibirica & acaaagaTGAAgttcgatc ${ }^{*}$ & GenBank: AB455836.1 \\
& & Given study (GenBank: & MH443094, MH443095, \\
& & & MH443096, MH443097) \\
& P. pumila & acaaagaTTAAgttcgatc & GenBank: AB019870.1 \\
& & Given study (GenBank: \\
& & MH443090, MH443091, \\
& & \\
& & MH443092, MH443093) \\
\hline Capital letters show restriction site for Tru9I that is present in P. pumila and absent in P. sibirica
\end{tabular}

\section{Results}

Using cytoplasmic DNA markers, we analyzed 59 P. sibirica trees and 32 P. pumila trees grown in the north-east of the sympatry zone. All P. pumila trees had species-specific cytoplasmic DNA loci (Table 3). In contrast, no P. sibirica trees had sibirica-specific mtDNA locus but pumila-like. CpDNA of the studied $P$. sibirica trees was frequently typical for the species, but some trees (17 $\%)$ had a pumila-specific trnV locus. Hence, all trees with P. sibirica appearance were hybrids.

Analyzed trnV intron was the same in all P. pumila trees, but some polymorphism was found in four individuals, three $P$. pumila trees and one sibirica-like hybrid. This polymorphism consisted of an insertion of a GAAA-motif (GeneBank: MH443098, MH443099). All obtained sequences with TGAA fragment in TrnV intron (P. sibirica variant) did not have this insertion. The reported hybrid had pumila-specific (TTAA) variant of trnV intron, and so this insertion was inherited only in $P$. pumila. 
Table 3

Types of cytoplasmic genome found in P. sibirica and P. pumila trees identified morphologically

\begin{tabular}{lcccc}
\hline Cytoplasmic DNA loci & \multicolumn{2}{c}{ Aldan } & \multicolumn{2}{c}{ Tommot } \\
\cline { 2 - 5 } & P. sibirica & P. pumila & P. sibirica & P. pumila \\
\cline { 2 - 5 } & $\mathrm{N}=15$ & $\mathrm{~N}=15$ & $\mathrm{~N}=44$ & $\mathrm{~N}=17$ \\
\hline nadl intron2-pumila type & 15 & 15 & 44 & 17 \\
nadl intron2-sibirica type & 0 & 0 & 0 & 0 \\
trnV-pumila type & 1 & 15 & 9 & 17 \\
trnV-sibirica type & 14 & 0 & 35 & 0 \\
\hline
\end{tabular}

\section{Discussion}

Only P. sibirica and P. pumila hybrids with intermediate traits have been described previously (Goroshkevich, 1999; 2004). Based on intermediate traits such hybrids were regarded as F1 (Goroshkevich et al., 2008). We suggest that traits of hybrids after multiple back-crosses with one of the parental species should be accompanied by their gradual shift in the direction of the species morphology.

Siberian stone pines investigated in the current study and originating from the north-east of their geographic distribution have a typical P. sibirica appearance. However, analysis of cytoplasmic DNA markers revealed traces of genetic exchange. We suggest these trees are nothing other than an echo of ancient introgression. Previously it was shown by means of allozyme analysis that species had different allele frequencies and that they were well differentiated from each other and from hybrids in the mixed hybrid populations from the Baikal region (Petrova et al., 2008; Petrova, Bender, 2010). Moreover, AFLP analysis also revealed clear division into two species and hybrid clusters in the mixed hybrid population in the south of the Baikal region (Vasilyeva and Semerikov, 2014). Therefore, we suppose that the hybridization pattern of the species is different in the different parts of the sympatry zone. On the one hand, the current process of gene flow between the species results in the intermediate $\mathrm{F} 1$ hybrid trees and occurs in the Baikal region. On the other hand, ancient introgression shown here occurs in the north-eastern part of the sympatry zone. The results obtained in this study suggest a repeated contact of the species ranges apparently due to global climate changes each of which could lead to hybridization. It is also possible that favorable conditions for genetic exchange were first developed in the north-eastern part of the current sympatry zone, and in the south-western part (i.e. the Baikal region) were sufficiently later.
It is interesting to note that the introgression of mtDNA we found was unidirectional. All trees morphologically identified as $P$. sibirica have pumila-specific mtDNA and mostly sibirica-specific cpDNA. However, there were no trees morphologically identified as $P$. pumila that have sibirica-specific cytoplasmic DNA markers. Flowering phenology and reproductive compatibility are of great importance for determination of the gene flow direction. It was shown that female cone development and pollen release in P. pumila occur earlier than in P. sibirica (Vasilyeva et al., 2010). In general, flowering phenology in these species is close enough to make individual variation and weather fluctuations provide gene flow in both directions. On the other hand, no evidence was found for unidirectional incompatibility between $P$. sibirica and $P$. pumila whose hybrids could be crosses with both parental species under controlled pollination conditions (Vasilyeva and Goroshkevich, 2013). Thus, unidirectional introgression of mtDNA could be caused by other currently undetermined factors.

It is difficult to discuss the timing of the introgression revealed because there is little available information concerning species origin and their geographic distribution path. Every recent study devoted to Pinus phylogeny has drawn attention to the possible effect of hybridization on establishment of a particular species or group of species (Syring et al., 2007; Tsutsui et al., 2009; Wang and Wang, 2014; Hao et al., 2015). It was shown in the five-needle pines that phylogenetic trees based on mtDNA, cpDNA and nuclear DNA did not coincide with each other (Tsutsui et al., 2009). Introgression was considered as one of the main factors leading to a phylogenetic incongruence. According to the cpDNA dataset, subsection Strobus (classification by Gernandt et al., 2005) splits into two groups, a Eurasian clade with North American P. albicaulis including all Eurasian species but not $P$. peuce, and the second group with the remaining five-needle pine species. In contrast, the mtDNA-based dataset demonstrated that group_2 includes all North American species and three Eurasian species, $P$. pumila, $P$. koraiensis and $P$. peuce, while the other species belong to a group_1. Eurasian P. pumila, P. koraiensis and North American $P$. albicaulis are characterized by cpDNA of the Eurasian clade and mtDNA of the group_2, mainly North American (Tsutsui et al., 2009). Hence, there is a reticulate component in the $P$. pumila origin possibly determining its predisposition to the interspecific genetic exchange. P. pumila hybridizes not only with P. sibirica but also with P. parviflora (Watano et al., 1995; 1996) which is very interesting for resembling of $P$. pumila and $P$. sibirica interspecific relation. P. pumila flowering also occurs earlier for several days compared with that of $P$. parviflora within the same locations (Ito et al., 2008). Pollen morphology is very similar in the P. pumila / P. sibirica pair (Kupriyanova and Litvintseva, 1974) and in the P. pumila / P. parviflora pair (Morita et al., 1999), making one-sided incompatibility unlikely. Hybridization of $P$. pumila and $P$. parviflora results in unidirectional introgression of mtDNA from the former species to the later one (Senjo et al., 1999). Thus, introgression takes place in the sympatry zone of $P$. pumila and closely related species ( $P$. sibirica and $P$. parviflora). In both cases, hybrid trees morphologically 
similar to upright species and having mtDNA of the prostrate species have been found. Why there are no hybrid trees with a $P$. pumila growth form and mtDNA of the upright species $(P$. sibirica or $P$. parviflora) remains unclear.

The novel information about the ancient introgression of $P$. sibirica and $P$. pumila resulting in formation of the cryptic hybrid populations of $P$. sibirica with a common habit but alien mtDNA could have an impact on understanding of the evolutionary relationships between the species and their differentiation in the sympatry zone. The most important questions to be further elucidated are geographic distribution of the ancient introgression and possible adaptive advantages of the cryptic hybrids over pure species.

\section{Acknowledgements}

This study was supported by the Russian Foundation for Basic Research (Project No 15-04-03924).

\section{References}

Anderson E (1953) Introgressive hybridization. Biol Rev 28(3): 280-307. https://doi.org/10.1111/j.1469-185x.1953.tb01379.x

Bobrov EG (1944) On the features of the flora of the erratic region (one of the ways of forming). Sovetskaja botanika 2: 3-20 (In Russian).

Bobrov EG (1961) Introgressive hybridization in the flora of the Baikalian Siberia. Botanical Journal 46(3): 313-327 (In Russian).

Burgess KS, M Morgan, L Deverno and BC Husband (2005) Asymmetrical introgression between two Morus species (M. alba, M. rubra) that differ in abundance. Mol Ecol 14: 3471-3483. https://doi.org/10.1111/j.1365-294X.2005.02670.x

Chen J, CG Tauer, G Bai, Y Huang, ME Payton and AG Holley (2004) Bidirectional introgression between Pinus taeda and Pinus echinata: evidence from morphological and molecular data. Can J For Res 34: 2508-2516. https://doi.org/10.1139/X04-134

Demesure B, Sodzi M, Petit RJ (1995) A set of universals primers for amplification of polymorphic non-coding regions of mitochondrial and chloroplast DNA in plants. Mol Ecol 4: 129-131. https://doi.org/10.1111/j.1365-294x.1995.tb00201.x

Doyle JJ and JL Doyle (1987) A rapid DNA isolation procedure for small quantities of fresh leaf tissue. Phytochem Bull 19: 11-15.

Gernandt DS, GG Lopez, SO Garcia and A Liston (2005) Phylogeny and classification of Pinus. Taxon 54(1): 29-42. https://doi.org/10.2307/25065300

Godbout J, FC Yeh and J Bousquet (2012) Large-scale asymmetric introgression of cytoplasmic DNA reveals Holocene range displacement in a North American boreal pine complex. Ecol Evol 2(8): 1853-1866. https://doi.org/10.1002/ece3.294

Goroshkevich SN (1999) On the possibility of natural hybridization between Pinus sibirica and Pinus pumila (Pinaceae) in the Baikal region. Botanical Journal. 84(9): 48-57 (In Russian).

Goroshkevich SN (2004) Natural hybridization between Russian stone pine (Pinus sibirica) and Japanese stone pine (Pinus pumila). In: Sniezko RA et al. (ed) Breeding and genetic resources of five-needle pines: growth, adaptability, and pest resistance. pp. 169-171

Goroshkevich SN, AG Popov and GV Vasilieva (2008) Ecological and morphological studies in the hybrid zone between Pinus sibirica and Pinus pumila. Ann For Res 51: 43-52.

Grant V (1981) Plant speciation. Columbia Univ. Press, New York, 563 pp ISBN 0231051131
Gugerli F, J Senn, M Anzidei, A Madaghiele, U Büchler, C Sperisen and JJ Vendramin (2001) Chloroplast microsatellites and mitochondrial nad 1 intron 2 sequences indicate congruent phylogenetic relationships among Swiss stone pine (Pinus cembra), Siberian stone pine (Pinus sibirica), and Siberian dwarf pine (Pinus pumila). Mol Ecol 10: 1489-1497.

https://doi.org/10.1046/j.1365-294x.2001.01285.x

Hao ZZ, YY Liu, M Nazaire, XX Wei and XQ Wang (2015) Molecular phylogenetics and evolutionary history of sect. Quinquefoliae (Pinus): implications for Northern Hemisphere biogeography. Mol Phylogenet Evol 87: 65-79. https://doi.org/10.1016/j.ympev.2015.03.013

Ito M, Y Suyama, TA Ohsawa and Y Watano (2008) Airborne-pollen pool and mating pattern in a hybrid zone between Pinus pumila and P. parviflora var. pentaphylla. Mol Ecol 17:5092-5103. https://doi.org/10.1111/j.1365-294X.2008.03966.x

Koropachinskiy IYu and LI Milyutin (2006) Natural hybridization of woody plants. Novosibirsk, Academic Publishing House "Geo", 223 pp. ISBN 5-9747-0034-1 (In Russian).

Kupriyanova LA and MV Litvintseva (1974) The group Cembrae of genus Pinus, its volume and relationships according to palynological data. Botanical Journal 59(5): 630-644 (In Russian).

Mogensen HL (1996) The hows and whys of cytoplasmic inheritance in seed plants. Am J Bot 83:383-404. https://doi.org/10.2307/2446172

Morita Y, K Ueda, H Kataoka, N Miyoshi (1999) The size-frequency of Japanese Pinus pollen. The Bulletin of Research Institute of Natural Sciences Okayama University of Science 25:73-86.

Neale DB and RR Sederoff (1989) Paternal inheritance of chloroplast DNA and maternal inheritance of mitochondrial DNA in loblolly pine. Theoret Appl Genetics 77(2): 212-216. https://doi.org/10.1007/BF00266189

Petit RJ, C Bodenes, A Ducousso, G Roussel and A Kremer (2004) Hybridization as a mechanism of invasion in oaks. New Phytol 161: 151-164. https://doi.org/10.1046/j.1469-8137.2003.00944.x

Petit RJ and GG Vendramin (2007) Phylogeography of organelle DNA in plants: an introduction. In: Weiss S, Ferrand N (eds) Phylogeography of Southern European Refugia. New York, USA: Springer, pp 23-97. ISBN 978-1-40204904-0

Petrova EA, SN Goroshkevich, MM Belokon, YS Belokon and DV Politov (2008) Population genetic structure and mating system in the hybrid zone between Pinus sibirica Du Tour and P. pumila (Pall.) Regel at the eastern Baikal Lake shore. Ann For Res 51: 19-30.

Petrova EA, SN Goroshkevich, DV Politov, MM Belokon, AG Popov and GV Vasilyeva (2007) Seed production and genetic structure of populations in natural hybrid zone of Siberian stone pine and Siberian dwarf pine. Khvoynyye borealnoy zony 24: 329-335 (In Russian).

Politov DV, MM Belokon, OP Maluchenko, YS Belokon, VN Molozhnikov, LE Mejnartowicz and KV Krutovsky (1999) Genetic evidence of natural hybridization between Pinus sibirica Du Tour and P. pumila (Pall.) Regel. Forest Genetics 6: 41-48.

Pozdnyakov LK (1969) Forests in the Yakutskaya ASSR. In: Forest of USSR. Vol. 4. Moscow, Nauka, pp 469-537 (In Russian).

Senjo M, K Kimura, Y Watano, K Ueda and T Shimizu (1999) Extensive mitochondrial introgression from Pinus pumila to P. parviflora var. pentaphylla (Pinaceae). J Plant Res 112: 97-105. https://doi.org/10.1007/PL00013867

Stebbins GL Jr (1959) The role of hybridization in evolution. Proc Am Phil Soc 103: 231-251.

Syring J, K Farrell, R Businsky, R Cronn and A Liston (2007) Widespread genealogical nonmonophyly in species of Pinus Subgenus Strobus. Syst Biol 56(2): 163-181. https://doi.org/10.1080/10635150701258787

Thórsson AT, E Salmela and K Anamthawat-Jónsson (2001) Morphological, cytogenetic, and molecular evidence for introgressive hybridization in birch. J Hered 92(5): 404-408. https://doi.org/10.1093/jhered/92.5.404

Tsutsui K, A Suwa, K Sawada, T Kato, TA Ohsawa and Y Watano (2009) Incongruence among mitochondrial, chloroplast and nuclear gene trees in Pinus subgenus Strobus (Pinaceae). J Plant Res 122: 509-521. https://doi.org/10.1007/s10265-009-0246-4

Vasilyeva GV and SN Goroshkevich (2013) Crossability of Pinus sibirica and P. pumila with their hybrids. Silvae Genetica 62(1-2):61-68. https://doi.org/10.1515/sg-2013-0008 
Vasilyeva GV (2014) Seed efficiency of hybrids between Siberian stone pine and Siberian dwarf pine from northern slope of Khamar-Daban ridge. Moscow state forest university bulletin. Lesnoj Vestnik 1: 85-90 (In Russian).

Vasilyeva GV, EA Zhuk and AG Popov (2010) Flowering phenology of the Siberian stone pine (Pinus sibirica Du Tour), Japanese stone pine (Pinus pumila (Pall.) Regel) and their hybrids. Tomsk State University Journal of Biology 1(9): 61-67 (In Russian, English summary)

Wang B and Wang XR (2014) Mitochondrial DNA capture and divergence in Pinus provide new insights into the evolution of the genus. Mol Phylogenet Evol 80: 20-30. https://doi.org/10.1016/j.ympev.2014.07.014

Watano Y, M Imazu and T Shimizu (1995) Chloroplast DNA typing by PCR-SSCP in the Pinus pumila-P. parviflora var. pentaphylla complex (Pinaceae). J Plant Res 108: 493-499. https://doi.org/10.1007/BF02344239

Watano Y, M Imazu and T Shimizu (1996) Spatial distribution of cpDNA and mtDNA haplotypes in a hybrid zone between Pinus pumila and P. parviflora var. pentaphylla (Pinaceae). J Plant Res 109: 403-408. https://doi.org/10.1007/BF02344555 